Short Note

\title{
Seasonal variation in the nutritional analysis of Caprella scaura (Amphipoda: Caprellidae) from the biofouling of fish farm cages in Central Greece
}

\author{
Alexios Lolas*, Pier Psofakis and Ioannis T. Karapanagiotidis
}

\author{
Dr. Alexios Lolas (https://orcid.org/0000-0002-9579-2674) \\ Post-Doctoral Researcher \\ Department of Ichthyology and Aquatic Environment, School of Agriculture Sciences, University of Thessaly, 38446 \\ Volos, Greece \\ *Correspondence: allolas@uth.gr
}

\section{Pier Psofakis M.Sc.}

Ph. D. Student

Department of Ichthyology and Aquatic Environment, School of Agriculture Sciences, University of Thessaly, 38446 Volos, Greece

email: aquariumpir@yahoo.gr

\author{
Dr. Ioannis T. Karapanagiotidis (https://orcid.org/0000-0002-5036-8706) \\ Associate Professor \\ Department of Ichthyology and Aquatic Environment, School of Agriculture Sciences, University of Thessaly, 38446 \\ Volos, Greece \\ email: ikarapan@uth.gr
}

\begin{abstract}
The total lipid and protein content of the invasive caprellid amphipod Caprella scaura, from the biofouling communities of fish farm cages in the Pagasitikos Gulf were analyzed and compared among seasons. Proteins were the most abundant component $(48.5-49.3 \%)$. Lipid content was relatively lower, with a wider range $(6.7-34 \%)$ and showed a distinct seasonal fluctuation with high values in the winter population and a gradual decrease in spring and summer, with the lowest values in Autumn. Composition of the fatty acids profile was consistent among the seasons, with palmitic (16:0), Oleic (18:1n-9), Eicosapentanoic (20:5n-3)(EPA) and Docosahexanoic acid (22:6n-3 )(DHA) being the most abundant fatty acids. The presence of high levels of EPA and DHA fatty acids makes the species a potential candidate for use of these organisms in aquaculture.
\end{abstract}

Keywords: fatty acids; lipid content; protein content; invasive species; Kjeldahl; Gas chromatography; Integrated Multi Trophic Aquaculture; Pagasitikos Gulf

\section{Introduction}

One of the most crucial challenges which humanity is facing nowadays is the pressing need to feed an ever growing population, but with the limited and finite natural resources available on our planet [1]. Seafood, in general, and especially fish, have always been an important part of the human diet and nowadays they represent an essential component of the global food basket, in terms of nutrition, health, and well-being of all people [2]. Aquaculture is a promising industry which could support this pressing need. In fact, aquaculture is considered one of the fastest growing animal food production sectors, and production will probably continue to grow to meet the rising demand for seafood [3], mainly owning to the generally static or declining capture fisheries [4].

However, aquaculture itself is also facing new challenges in terms of cost and ecological impact. Feeding the fish is often the costliest production input, and can have important 
downstream ecological effects. At present, many marine finfish aquaculture efforts are directed at high trophic level carnivorous fish that are often reliant upon on-growing aquafeeds derived from catches of lower trophic level fish, with increasing associated capture costs and biodiversity/ecosystem impacts [5].

Up to date, the aquaculture sector has focused on searching feedstuff alternatives from the terrestrial environment at a significant degree of success by using protein from plants [6], animals $[7,8]$ and even insects $[9,10]$. However, the marine aquatic environment is still not fully explored and could possibly provide credible and sustainable solutions for fishmeal and fishoil replacement. In this context, a promising feedstuff alternative could be proved to be the marine amphipods of the Caprellidae Family. These marine organisms have recently attracted the scientific interest of aquaculture researchers, as they are rich in animal protein and at the same time contain significant amounts of the, rarely found in nature, omega-3 fatty acids [4,11-13].

Caprellid amphipods have a number of suitable characteristics which make them a potential resource in the aquafeeds industry and aquaculture: (i) they have a widespread global distribution and can be easily found as the dominant species in biofouling communities attached to sea cages and fixed structures, (ii) they already consist part of the natural diet of several marine fish species, (iii) they exhibit high reproduction performance, fast growth rates and under appropriate conditions can reach high biomass $[4,13]$. Furthermore, caprellid amphipods could be also utilized as novel aquatic organisms as live feed in aquaculture, particularly for larval or juvenile finfish stages $[14,15]$. Currently, the aquaculture industry uses Artemia spp., rotifers, copepods and mysid shrimps as live feed for juvenile fish production, but these organisms are not nutritionally optimal, since they have low levels of essential fatty acids, so there is a need to enrich them prior to use thus increasing the cost of feeding [16]. Moreover, caprellid amphipods could be, also, utilized within the framework of an Integrated Multi-Trophic Aquaculture (IMTA), serving as extractive species which feed on detritus from the farmed fish, thus reducing the environmental impact of the farming process [13].

The aim of this study was to analyze the nutritional content of the invasive caprellid amphipod Caprella scaura, from the natural occurring populations on the fish cages from an aquaculture facility in Pagasitikos gulf, Greece. Our main focus was the fatty acid profile, crude lipid and protein content and if there are any fluctuations between the seasons.

\section{Materials and Methods}

Samples of the biofouling community, including C. scaura populations, were collected following a similar technique described in Lolas, et al. [17]. Plastic meshes were used as an artificial substrate for biofouling to establish and develop and were submerged very close to the nets of the fish cages. The initial deployment commenced in early June 2018 and the meshes were left submerged for 3 months, then collected and replaced with new ones every 3 months, in order for each batch to represent one season (Summer, Autumn, Winter, Spring). During their collection each season, meshes were put in plastic containers filled with sea water and were then transferred to the laboratory. They were, then, rinsed with tap water and sieved through a $250 \mu \mathrm{m}$ mesh in order to collect the majority of the fouling fauna. Because of the distinctive morphology of $C$. scaura, mature male and female individuals were easily sorted out from the rest of the fauna and were stored in glass vials in deep freeze conditions $\left(-80^{\circ} \mathrm{C}\right)$.

Lipid fraction was extracted from the wet biomass of $C$. scaura individuals, according to the method described by Folch, et al. [18] and three replicates for each season were analyzed. The crude protein content was determined with Kjeldahl analyses, using a conversion factor of 6.25 [19].Total lipid was extracted using a chloroform:methanol solution (C:M 2:1 V/V) containing $0.05 \%(\mathrm{~W} / \mathrm{V})$ of butylated hydroxytoluene (BHT) as an antioxidant agent. Organic solvents where evaporated with a stream of nitrogen until dried and lipid content was determined gravimetrically. Extracted lipids were stored in C:M (2:1, v/v) with a standard concentration of $20 \mathrm{mg}$ lipid $\mathrm{mL}^{-1}$.

Fatty acid methyl esters (FAME) were prepared by acid catalyzed transesterification according to [20]. Extracted lipid sample containing $1 \mathrm{mg}$ of total lipids and $0.1 \mathrm{mg}$ heptadecanoic acid (17:0) (Sigma Chemical Company, St. Louis, MO, USA) as internal standard was evaporated 
under a stream of nitrogen. $2 \mathrm{~mL}$ of methylating agent was added containing sulfuric acid in methanol $\left(1 \% \mathrm{H}_{2} \mathrm{SO}_{4}\right.$ in methanol) and $1 \mathrm{~mL}$ of toluene. Vials were flashed with nitrogen and dry incubated on a hot block (SC154-240, Environmental Express, SC, USA) at $50^{\circ} \mathrm{C}$ for $16 \mathrm{~h}$. Crude FAMEs were purified by thin layer chromatography (TLC) on $20 \times 20 \mathrm{~cm}$ glass plate pre-coated with silica gel G (Merc silica gel 60), developed in a isohexane: diethyl ether: acetic acid (90:10:1, $\mathrm{v} / \mathrm{v})$ solution and visualized with a $1 \%(\mathrm{~W} / \mathrm{V})$ iodine in $\mathrm{CH}_{3} \mathrm{Cl}_{3}$ solution. After scraping silica gel containing FAMEs, they were removed by elution with an isohexane: diethyl ether $(1: 1, \mathrm{~V} / \mathrm{V})$ solution and re-dissolved in isohexane containing $0.05 \%$ BHT as an antioxidant agent. Vials containing the samples were flashed with nitrogen prior storage at $-80^{\circ} \mathrm{C}$.

Separation and quantification of FAMEs was conducted by Gas-Liquid chromatography (GLC) with a Perkin Elmer Clarus 680 coupled with a Col-Elite FAME Wax capillary column (30 $\mathrm{m} \times 0.25 \mathrm{~mm}$ id, film thickness $0.25 \mu \mathrm{m}$ ) (PN N9316694, Perkin Elmer, Waltham, MA, USA). Hydrogen was the carrier gas with constant flow rate of $1 \mathrm{~mL} \mathrm{~min}^{-1}$. Injector temperature was set at $240^{\circ} \mathrm{C}$ with a split ratio of $1: 10$ at a total flow rate of $5 \mathrm{~mL} \mathrm{~min}{ }^{-1}$. The column oven was programmed from $60^{\circ} \mathrm{C}$ to $190^{\circ} \mathrm{C}$ for $5 \mathrm{~min}$ at a rate of $20^{\circ} \mathrm{C} \mathrm{min}{ }^{-1}$ and from $190^{\circ} \mathrm{C}$ to $240^{\circ} \mathrm{C}$ at a rate of $5 \mathrm{C} \mathrm{min}^{-1}$. The final temperature was maintained for $20 \mathrm{~min}$. Identification of individual FAMES were conducted by comparison to known standards (CL40.13093, FAME MIX 37, SigmaAldrich, St. Louis, MO, USA). Peak areas were quantified with reference to the peak area of 17:0 as an internal standard.

\section{Results}

According to the analyses, C. scaura was characterized by high levels of crude protein content $(48.5-49.3 \%)$ with no apparent seasonal fluctuation. On the contrary, lipid content seemed to follow a seasonal pattern, with significant differences among the seasons, with relatively high values in the Winter population (34\%), lower values in Spring and Summer (17.5 and 16.3\%) and the lowest values in Autumn (6.7\%) (Figure 1). The saturated fatty acids (SFA) ranged between $34.4-36.5 \%$ of the total fatty acids in C. scaura, the polyunsaturated fatty acids (PUFA) were between $33.5-36.3 \%$ and the monounsaturated (MUFA) were $28.0-33.7 \%$ (Table 1).
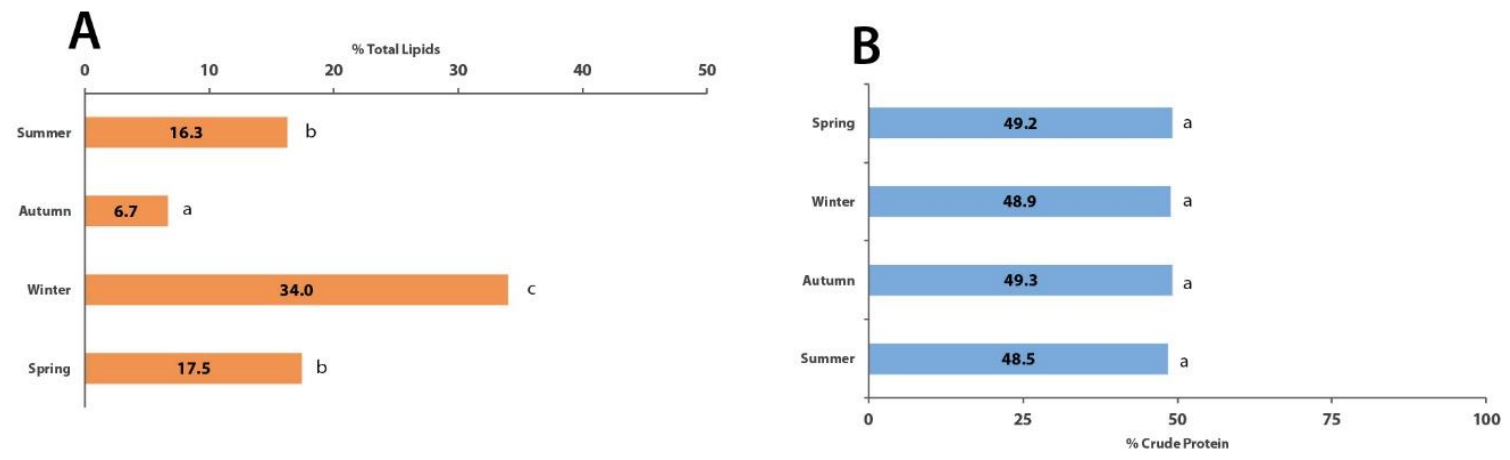

Figure 1. Seasonal values of the percentage per wet weight (\%) of total lipids (A) and crude protein (B) of Caprella scaura from fish cages in Pagasitikos gulf, Greece. Values with different letter are significantly different 
Table 1. Percentage of fatty acid composition of Caprella scaura from fish cages in Pagasitikos gulf, Greece. SFA: Saturated Fatty Acids; MUFA: Monounsaturated Fatty Acids; PUFA: Polyunsaturated Fatty Acids; EPA: Eicosapentanoic acid; DHA: Docosahexanoic acid.

\begin{tabular}{|c|c|c|c|c|}
\hline Fatty Acids & Summer & Autumn & Winter & Spring \\
\hline \multicolumn{5}{|l|}{$S F A$} \\
\hline 12:0 & 0.5 & 0.2 & 0.4 & 0.4 \\
\hline 14:0 & 2.3 & 2.6 & 2.5 & 2.5 \\
\hline 15:0 & 0.8 & 0.6 & 0.8 & 0.7 \\
\hline $16: 0$ & 22.8 & 24.2 & 24.7 & 25.0 \\
\hline 18:0 & 5.0 & 4.8 & 5.1 & 5.2 \\
\hline 20:0 & 1.8 & 2.0 & 2.0 & 2.1 \\
\hline 22:0 & 1.0 & 0.5 & 0.9 & 0.7 \\
\hline Total & 34.4 & 34.9 & 36.4 & 36.5 \\
\hline \multicolumn{5}{|l|}{ MUFA } \\
\hline $16: 1 n-9$ & 0.9 & 0.6 & 0.9 & 0.6 \\
\hline $16: 1 n-7$ & 5.9 & 3.8 & 4.9 & 4.8 \\
\hline $18: 1 n-9$ & 16.5 & 22.2 & 21.1 & 17.1 \\
\hline 18:1n-7 & 3.6 & 2.6 & 3.7 & 2.9 \\
\hline 20:1n-9/n-11 & 1.5 & 1.7 & 1.7 & 1.5 \\
\hline $22: 1 n-9 / n-11$ & 0.3 & 0.3 & 0.3 & 0.3 \\
\hline $24: 1 n-9$ & 1.3 & 0.6 & 1.0 & 0.7 \\
\hline Total & 30.0 & 31.6 & 33.7 & 28.0 \\
\hline \multicolumn{5}{|l|}{ PUFA n-6 } \\
\hline $18: 2 n-6$ & 7.4 & 10.3 & 9.1 & 8.3 \\
\hline $18: 3 n-6$ & 5.0 & 0.5 & 3.1 & 4.1 \\
\hline $20: 2 n-6$ & 0.1 & 0.2 & 0.1 & 0.2 \\
\hline $20: 3 n-6$ & n.d. & n.d. & n.d. & n.d. \\
\hline $20: 4 n-6$ & 2.9 & 4.1 & 3.4 & 3.7 \\
\hline $22: 4 n-6$ & 1.8 & 0.6 & 1.7 & 1.0 \\
\hline $22: 5 n-6$ & 1.7 & 0.9 & 1.2 & 1.0 \\
\hline Total & 18.8 & 16.6 & 18.6 & 18.2 \\
\hline \multicolumn{5}{|l|}{ PUFA n-3 } \\
\hline $18: 3 n-3$ & 0.6 & 0.9 & 0.6 & 0.9 \\
\hline $18: 4 n-3$ & 0.3 & 0.3 & 0.3 & 0.3 \\
\hline $20: 3 n-3$ & n.d. & n.d. & n.d. & n.d. \\
\hline $20: 4 n-3$ & 0.3 & 0.2 & 0.3 & 0.2 \\
\hline 20:5n-3 (EPA) & 8.4 & 8.3 & 8.8 & 8.0 \\
\hline $22: 5 n-3$ & 0.6 & 0.7 & 0.8 & 0.7 \\
\hline 22:6n-3 (DHA) & 6.8 & 6.6 & 6.9 & 6.6 \\
\hline Total & 17.0 & 16.9 & 17.7 & 16.7 \\
\hline Total PUFA & 35.7 & 33.5 & 36.3 & 34.9 \\
\hline Ratio (n-6):(n-3) & 0.90 & 1.02 & 0.95 & 0.92 \\
\hline
\end{tabular}


The most predominant fatty acids (FA) in C. scaura content were the saturated 16:0 (22.8 $25.0 \%)$ and the monounsaturated 18:1n-9 (16.5 - 22.2\%), whereas the very important PUFA Eicosapentanoic acid (EPA) and Docosahexanoic acid (DHA) were found in relatively lower values but still, higher than most of the other FA and they could actually be considered as adequate (EPA $8.0-8.8 \%$ and DHA $6.6-6.9 \%$ ).

\section{Discussion}

The fatty acid (FA) profile of C. scaura was characterized by the presence of four major FAs, 16:0, 18:1n-9, 20:5n-3 (EPA) and 22:6n-3 (DHA). These FAs were also found to be the most dominant in several other studies, either in caprellids $[4,11,12,21]$ but also other groups of amphipods [15,22-24]. Although content levels vary between locations and species, which is something to be expected, the consistent abundance of those four important FAs in amphipods shows that they actually could be a promising natural marine resource in the aquaculture sector.

The small differences in content values of FAs in C. scaura among the seasons did not follow a specific pattern. Although temperature is known to affect the composition of the FA profile in marine amphipods [21], this did not seem to be the case for C. scaura from Pagastikos gulf. Although some unidentified peaks were detected during the chromatographic analyses, which could potentially indicate that other FAs were also present, the identified FAs were quite consistent among the seasonal samples. On the other hand, total lipid content was evidently affected by water temperature, since it followed a specific seasonal pattern. Marine amphipods, caprellids included, follow a certain nutritional strategy which dictates the storing of energy in lipid reserves to cope with the changes in feed availability during the low winter temperatures [25]. These energy reserves are then being used during the spring and summer reproduction and growth, which are the main processes involved in the metabolism of lipids [26].

Based on the composition of the FA profile of amphipods, a wide range of ratios can be calculated which sometimes are considered as bioindicators of diet preference [22,27]. In the case of C. scaura from fish cages in Pagasitikos gulf, the ratio EPA/DHA which is an indicator of a diatom-based diet [22,27], was lower than the ratio 18:1(n-9)/ 18:1(n-7) which is an indicator for a more carnivorous preference [28]. This finding is in agreement with the predation attribute which characterizes the feeding behavior of C. scaura [29-32]. This aggressive behavioral trait could also be one of the factors which enhance the invasive success that $C$. scaura by displacing congeneric species from their niche, such as Caprella equilibra [17,33-35].

It seems that there is a considerable potential for the use of $\mathrm{C}$. scaura as a key resource in the aquaculture sector. Its nutritional value can be considered, at least, adequate [13,36]. In this context, it could be either harvested from natural occurring populations or from dedicated artificial substrates, integrated within in the IMTA framework or even intensively cultivated on a large scale, in order to make its exploitation more sustainable $[4,13,36]$. Further studies are required both in local and regional level in regards to the estimation of favorable conditions which could maximize the biomass growth and nutritional output for the harvested / cultivated products and would be very beneficial, in this regard.

Author Contributions: Conceptualization, A.L. and I.K.; methodology, A.L., I.K. and P.P; formal analysis, A.L. and P.P.; investigation, A.L.; resources, A.L. and P.P; data curation, A.L and P.P.; writing-original draft preparation, A.L. and I.K.; writing - review and editing, P.P. and I.K.; visualization, A.L.; supervision, I.K.; project administration, I.K.; funding acquisition, A.L. All authors have read and agreed to the final version of the manuscript.

Funding: This research was supported by a postdoctoral scholarship program (Project number: 5394.02.01), implemented by University of Thessaly and funded by the Stavros Niarchos Foundation.

Acknowledgments: The authors would like to thank the graduate students Mr. Pasintelis K. and Mrs. Psyrra E. for their valuable help during the samplings and lab analyses. 
Data Availability Statement: Data are available from correspondent authors.

Conflicts of Interest: The authors declare no conflict of interest. The funders had no role in the design of the study; in the collection, analyses, or interpretation of data; in the writing of the manuscript, or in the decision to publish the results.

\section{References}

1. Naylor, R.L.; Hardy, R.W.; Bureau, D.P.; Chiu, A.; Elliott, M.; Farrell, A.P.; Forster, I.; Gatlin, D.M.; Goldburg, R.J.; Hua, K., et al. Feeding aquaculture in an era of finite resources. Proceedings of the National Academy of Sciences 2009, 106, 15103-15110, doi:10.1073/pnas.0905235106.

2. Tacon, A.G.J.; Metian, M. Fish Matters: Importance of Aquatic Foods in Human Nutrition and Global Food Supply. Reviews in Fisheries Science 2013, 21, 22-38, doi:10.1080/10641262.2012.753405.

3. Klinger, D.H.; Levin, S.A.; Watson, J.R. The growth of finfish in global open-ocean aquaculture under climate change. Proceedings of the Royal Society B: Biological Sciences 2017, 284, 20170834, doi:10.1098/rspb.2017.0834.

4. Woods, C.M.C. Caprellid amphipods: An overlooked marine finfish aquaculture resource? Aquaculture 2009, 289, 199-211, doi:10.1016/j.aquaculture.2009.01.018.

5. Tacon, A.G.J.; Metian, M. Global overview on the use of fish meal and fish oil in industrially compounded aquafeeds: Trends and future prospects. Aquaculture 2008, 285, 146-158, doi:10.1016/j.aquaculture.2008.08.015.

6. Jannathulla, R.; Rajaram, V.; Kalanjiam, R.; Ambasankar, K.; Muralidhar, M.; Dayal, J.S. Fishmeal availability in the scenarios of climate change: Inevitability of fishmeal replacement in aquafeeds and approaches for the utilization of plant protein sources. Aquaculture Research 2019, 50, 3493-3506, doi:10.1111/are.14324.

7. Karapanagiotidis, I.T.; Psofakis, P.; Mente, E.; Malandrakis, E.; Golomazou, E. Effect of fishmeal replacement by poultry by-product meal on growth performance, proximate composition, digestive enzyme activity, haematological parameters and gene expression of gilthead seabream (Sparus aurata). Aquaculture Nutrition 2019, 25, 3-14, doi:10.1111/anu.12824.

8. Psofakis, P.; Karapanagiotidis, I.T.; Malandrakis, E.E.; Golomazou, E.; Exadactylos, A.; Mente, E. Effect of fishmeal replacement by hydrolyzed feather meal on growth performance, proximate composition, digestive enzyme activity, haematological parameters and growth-related gene expression of gilthead seabream (Sparus aurata). Aquaculture 2020, 521, 735006, doi:10.1016/j.aquaculture.2020.735006.

9. Rumbos, C.I.; Mente, E.; Karapanagiotidis, I.T.; Vlontzos, G.; Athanassiou, C.G. Insect-Based Feed Ingredients for Aquaculture: A Case Study for Their Acceptance in Greece. Insects 2021, 12, doi:10.3390/insects12070586.

10. Henry, M.; Gasco, L.; Piccolo, G.; Fountoulaki, E. Review on the use of insects in the diet of farmed fish: Past and future. Animal Feed Science and Technology 2015, 203, 1-22, doi:10.1016/j.anifeedsci.2015.03.001.

11. Guerra-García, J.M.; Martínez-Pita, I.; Pita, M.L. Fatty acid composition of the Caprellidea (Crustacea: Amphipoda) from the Strait of Gibraltar. Scientia Marina 2004, 68, 501-510, doi:10.3989/scimar.2004.68n4501.

12. Cook, E.J.; Shucksmith, R.; Orr, H.; Ashton, G.V.; Berge, J. Fatty acid composition as a dietary indicator of the invasive caprellid, Caprella mutica (Crustacea: Amphipoda). Marine Biology 2010, 157, 19-27, doi:10.1007/s00227-009-1292-0.

13. Guerra-García, J.M.; Hachero-Cruzado, I.; González-Romero, P.; Jiménez-Prada, P.; Cassell, C.; Ros, M. Towards Integrated Multi-Trophic Aquaculture: Lessons from Caprellids (Crustacea: Amphipoda). PLOS ONE 2016, 11, e0154776, doi:10.1371/journal.pone.0154776.

14. Baeza-Rojano, E.; García, S.; Garrido, D.; Guerra-García, J.M.; Domingues, P. Use of Amphipods as alternative prey to culture cuttlefish (Sepia officinalis) hatchlings. Aquaculture 2010, 300, 243-246, doi:10.1016/j.aquaculture.2009.12.029.

15. Padovani, L.N.; Viñas, M.D.; Sánchez, F.; Mianzan, H. Amphipod-supported food web: Themisto gaudichaudii, a key food resource for fishes in the southern Patagonian Shelf. Journal of Sea Research 2012, 67, 85-90, doi:10.1016/j.seares.2011.10.007. 
16. Conceição, L.E.C.; Yúfera, M.; Makridis, P.; Morais, S.; Dinis, M.T. Live feeds for early stages of fish rearing. Aquaculture Research 2010, 41, 613-640, doi:10.1111/j.1365-2109.2009.02242.x.

17. Lolas, A.; Karapanagiotidis, I.T.; Panagiotaki, P.; Vafidis, D. Spreading and Establishment of the Non Indigenous Species Caprella scaura (Amphipoda: Caprellidae) in the Central Region of the Aegean Sea (Eastern Mediterranean Sea). Journal of Marine Science and Engineering 2021, 9, doi:10.3390/jmse9080857.

18. Folch, J.; Lees, M.; Stanley, G.H.S. A simple method for the isolation and purifcation of total lipid from animal tissues. Journal of Biological Chemistry 1957, 226, 497-509, doi:10.1016/S0021-9258(18)64849-5.

19. Metsoviti, M.N.; Katsoulas, N.; Karapanagiotidis, I.T.; Papapolymerou, G. Effect of nitrogen concentration, two-stage and prolonged cultivation on growth rate, lipid and protein content of Chlorella vulgaris. Journal of Chemical Technology $\mathcal{E}$ Biotechnology 2019, 94, 1466-1473, doi:10.1002/jctb.5899.

20. Bouras, S.; Katsoulas, N.; Antoniadis, D.; Karapanagiotidis, I.T. Use of Biofuel Industry Wastes as Alternative Nutrient Sources for DHA-Yielding Schizochytrium limacinum Production. Applied Sciences 2020, 10, doi:10.3390/app10124398.

21. Kawashima, H.; Takeuchi, I.; Ohnishi, M. Fatty Acid Compositions in Four of Caprellid Amphipod Species (Crustacea) from Otsuchi and Mutsu Bays in Northern Japan. Journal of Japan Oil Chemists' Society 1999, 48, 595-599, doi:10.5650/jos1996.48.595.

22. Auel, H.; Harjes, M.; da Rocha, R.; Stübing, D.; Hagen, W. Lipid biomarkers indicate different ecological niches and trophic relationships of the Arctic hyperiid amphipods Themisto abyssorum and T. libellula. Polar Biology 2002, 25, 374-383, doi:10.1007/s00300-001-0354-7.

23. Correia, A.D.; Costa, M.H.; Luis, O.J.; Livingstone, D.R. Age-related changes in antioxidant enzyme activities, fatty acid composition and lipid peroxidation in whole body Gammarus locusta (Crustacea: Amphipoda). Journal of Experimental Marine Biology and Ecology 2003, 289, 83-101, doi:10.1016/S00220981(03)00040-6.

24. Baeza-Rojano, E.; Hachero-Cruzado, I.; Guerra-García, J.M. Nutritional analysis of freshwater and marine amphipods from the Strait of Gibraltar and potential aquaculture applications. Journal of Sea Research 2014, 85, 29-36, doi:10.1016/j.seares.2013.09.007.

25. Richard, F.L.; Wilhelm, H.; Gerhard, K. Lipid storage in marine zooplankton. Marine Ecology Progress Series 2006, 307, 273-306, doi:10.3354/meps307273.

26. Watts, J.; Tarling, G.A. Population dynamics and production of Themisto gaudichaudii (Amphipoda, Hyperiidae) at South Georgia, Antarctica. Deep Sea Research Part II: Topical Studies in Oceanography 2012, 59-60, 117-129, doi:10.1016/j.dsr2.2011.05.001.

27. Nelson, M.M.; Mooney, B.D.; Nichols, P.D.; Phleger, C.F. Lipids of Antarctic Ocean amphipods: food chain interactions and the occurrence of novel biomarkers. Marine Chemistry 2001, 73, 53-64, doi:10.1016/S0304-4203(00)00072-4.

28. Falk-Petersen, S.; Hagen, W.; Kattner, G.; Clarke, A.; Sargent, J. Lipids, trophic relationships, and biodiversity in Arctic and Antarctic krill. Canadian Journal of Fisheries and Aquatic Sciences 2000, 57, 178191, doi:10.1139/f00-194.

29. Guerra-García, J.M.; Tierno de Figueroa, J.M. What do caprellids (Crustacea: Amphipoda) feed on? Marine Biology 2009, 156, 1881-1890, doi:10.1007/s00227-009-1220-3.

30. Prato, E.; Parlapiano, I.; Biandolino, F. Seasonal fluctuations of some biological traits of the invader Caprella scaura (Crustacea: Amphipoda: Caprellidae) in the Mar Piccolo of Taranto (Ionian Sea, southern Italy). Scientia Marina 2013, 77, doi:10.3989/scimar.03631.21B.

31. Guerra-García, J.M.; Ros, M.; Baeza-Rojano, E. Seasonal fluctuations and dietary analysis of fouling caprellids (Crustacea: Amphipoda) from marinas of southern Spain. Marine Biology Research 2015, 11, 703-715, doi:10.1080/17451000.2014.985231.

32. Molina, S.; Ros, M.; Guerra-García, J.M. Distribution of the Invasive Caprellid Caprella scaura (Crustacea: Amphipoda) in Cádiz Marina, Southern Spain: Implications for its Dispersal. Thalassas: An International Journal of Marine Sciences 2017, 33, 81-86, doi:10.1007/s41208-017-0024-3.

33. Guerra-García, J.M.; Ros, M.; Dugo-Cota, A.; Burgos, V.; Flores-León, A.M.; Baeza-Rojano, E.; Cabezas, M.P.; Núñez, J. Geographical expansion of the invader Caprella scaura (Crustacea: Amphipoda: 
Caprellidae) to the East Atlantic coast. Marine Biology 2011, 158, 2617-2622, doi:10.1007/s00227-0111754-z.

34. Ros, M.; Guerra-García, J.M.; González-Macías, M.; Saavedra, Á.; López-Fe, C.M. Influence of fouling communities on the establishment success of alien caprellids (Crustacea: Amphipoda) in Southern Spain. Marine Biology Research 2013, 9, 261-273, doi:10.1080/17451000.2012.739695.

35. Fernandez-Gonzalez, V.; Sanchez-Jerez, P. First occurrence of Caprella scaura Templeton, 1836 (Crustacea: Amphipoda) on off-coast fish farm cages in the Mediterranean Sea. Helgoland Marine Research 2014, 68, 187-191, doi:10.1007/s10152-013-0375-y.

36. Baeza-Rojano, E.; Calero-Cano, S.; Hachero-Cruzado, I.; Guerra-García, J.M. A preliminary study of the Caprella scaura amphipod culture for potential use in aquaculture. Journal of Sea Research 2013, 83, 146-151, doi:10.1016/j.seares.2013.04.014. 